\title{
Symptomatology, hosts, and pathogenicity of Corynespora cassiicola
}

\author{
Alicionon de Oliveira Caetano ${ }^{1}$, Rayane Louise Candida Diniz ${ }^{1}$, Natanael Marcos Lemes ${ }^{1}$, \\ Anderson Rodrigues Rietjens ${ }^{1}$, Milton Luiz da Paz Lima ${ }^{1}$ \\ ${ }^{1}$ Instituto Federal Goiano, Campus Urutaí, Urutaí, Goiás, Brasil. E-mail: sonoum.16@ hotmail.com, rayanelouise@ yahoo.com.br, \\ natanaelmarcos20@gmail.com, andersonrietjens1@gmail.com, milton.lima@ifgoiano.edu.br
}

Recebido: 27/12/2016; Aceito: 25/01/2018.

\section{RESUMO}

Many diseases are affecting tomato fruits in the field and greenhouse. The objective of this work was to identify, to verify the symptomatology, pathogenicity and hosts of $C$. cassiicola causal agent of tomato fruit rot. Symptomatic tomato fruit were isolated in medium agar-water (AW). After 48 hours, the mycelia were replicated on potato-dextrose-agar (PDA) medium. The inoculation was used mycelia discs, for treatments with and without injury, in fruits of tomato, okra, bell pepper, eggplant, zucchini, and noni were present. Both treatments, confirming the aggressiveness and pathogenicity on the original host. Among the other hosts, pathogenicity was confirmed only in okra, bell pepper, and tomato, in treatments with injury only. The comparative analysis, with the descriptions of the species, allowed the identification of the isolate as C. cassiicola, as fungi causal agent of rot fruit by tomato.

Key words: inoculation, aggressiveness, virulent, taxonomy, Solanum lycopersicon.

\section{Sintomatologia, hospedeiros e patogenicidade de Corynespora cassiicola}

\begin{abstract}
Muitas são as doenças que afetam frutos de tomateiro a campo e casa-de-vegetacao. O objetivo deste trabalho foi identificar, verificar e reconhecer a sintomatologia, patogenicidade e hospedeiros de $C$. cassiicola agente causal da podridão-de-frutos-do-tomateiro. Foram recebidos frutos de tomateiro sintomáticos onde realizou-se isolamento direto em meio ágar-água (AA), após 48 horas repicou-se para meio batata-dextrose-ágar (BDA). Inoculou-se discos de micélio em seis tratamentos representados por frutos de tomate, quiabo, pimentão, berinjela, abobrinha e noni, em inoculados com e sem ferimento. A patogenicidade foi confirmada somente para quiabo e pimentão, nos tratamentos com ferimento, somente. A análise comparativa das estruturas morfológicas e morfométricas com a descrição da espécie permitiu identificar o isolado como sendo Corynespora cassiicola.
\end{abstract}

Palavras-chave: inoculação, agressividade, virulência, taxonomia, Solanum lycopersicon. 


\section{Introduction}

Tomato (Solanum lycopersicon Mill. - Solanaceae) is one of the most important vegetables in Brazil. Originally from South America, it was domesticated in Mexico, and introduced to Europe around 1544. Its botanical family includes other important vegetables such as potato, tobacco, bell pepper, and eggplant, which can represent hosts of Corynespora rot (LOPES; AVILA, 2005). The consumption of tomato fruit contributes to a healthy and well-balanced diet because they are rich in minerals, vitamins, essential amino acids, sugars, and dietary fiber; and they contain large amounts of vitamins $\mathrm{B}$ and $\mathrm{C}$, iron and phosphorus (NAIKA et al., 2006).

The fruit consists of a rounded fleshy berry with smooth or ribbed surface, ranging in color from yellow to red. Its shape varies depending on how it is cultivated. Irrigation shortage and prolonged dry periods cause the fall of buds and flowers, as well as cracks on the fruit. However, when the humidity is high or there is excessive irrigation, the development of pathogens may occur, causing the fruit to rot (NAIKA, 2006; SILVA; GIORDANO, 2000).

In 2014, there was a reduction in crop yield due to high whitefly (Bemisia tabaci Gennadius) infestation in Brazil, decrease by up to $50 \%$ the production in some regions. The volume produced worldwide grew around $16 \%$ in 2014, and around $7 \%$ in Brazil (1.6 million tons compared to 2013). Among all the countries exporting the product, the largest increase was for China, around $43 \%$, with its production reaching 5.5 million tons (NASCIMENTO et al., 2014).

Losses in Brazil are higher in the post-harvest stage, in which they are more evident, and can reach $32 \%$. In retail, physical damage caused by transport and inadequate handling of the fruit can cause the onset of various postharvest diseases, from small patches to full rot (HENZ; MORETTI, 2005). Therefore, there is a reduction in the production and quality of the fruit, making it unusable for commercialization. Beyond the fruit, pathogens cause the reduction of vegetative growth, due to the rapid collapse in the leaf tissue, and can cause lesions on the stem and petiole as well (LEROY; LOURD, 1989; PERNEZNY; SIMON, 1999).

The plant pathogen Corynespora cassiicola (Berk. \& M.A. Curtis) C.T. Wei (1950) is widely distributed in the tropics and has been reported in a large number of host plants, such as cocoa, papaya, soybean, and tomato (LOPES; SANTOS, 1994). It appears in some ornamental plants as well, as poinsettia and hydrangea; weeds, as spiderwort and roast-fish; and other vegetables, as pumpkin, cucumber, bell pepper, tomato, okra, and vinegar (CUTRIM; SILVA, 2003). The fungi C. cassiicola infects 375 plant species, from more than
76 countries worldwide, and presents symptoms of decay both on the leaf and on the fruit. In Brazil 23 species of hosts have been recorded as papaya, coffee, eucalyptus, soybean, tomato, bean and sorghum (SILVA et al., 1995; FARR; ROSSMAN, 2018). There are even records of infections by $C$. cassiicola in humans, involved in subcutaneous phaeohyphomycosis infection, which have been treated with terbinafine and povidone iodine (HUANG et al., 2010).

The fungus was first reported in Brazil in the states of MT in 1974 on PR in 1976 for Almeida et al. (1976). Since then it has caused severe damage in all states, however sporadic and endemic, and there is evidence of its propensity in regions of colder climate. The pathogen C. cassiicola (Berk. and Curt.) Wei, may also be described and identified in literature as Cercospora melonis Cooke, C. vignicola Kawamura (1931), Helminthosporium vignae Olive (1945), and Helminthosporium vignicola (Kawamura) Olive (1949) (SNOW; BERGGREN, 1989; INDEX FUNGORUM, 2015).

The imperfect phase by $C$. cassiicola belongs to the uncertain group of Fungi Mitosporic, sub-group of hyphomycetes, genus Corynespora sp., and species $C$. cassiicola, with only one variant called $C$. cassiicola f.sp. lantanae J.M. Pereira, R.W. Barreto, C.A. Ellison \& Maffia (2003) (INDEX FUNGORUM, 2015). It presents fruiting without forming stroma, simple conidiophores, erect, unbranched, with dark brown color, containing four to fifteen septa, with swollen basal cells. Conidia are solitary under natural conditions, are formed at the end of conidiophore, and may have various forms (LEROY; LOURD, 1989) with light-brown staining hyaline (PERNEZNY; SIMON, 1999).

The objective of this work was to identify, to verify the symptomatology, pathogenicity and hosts of $C$. cassiicola causal agent of tomato fruit rot (Lycopersicon esculentum).

\section{Material and Methods}

The work was conducted and performed in the laboratory, on IFGoiano, in 2012, in Urutaí, GO, Brazil. Tomato fruits grown in greenhouse presenting symptoms were collected and with the aid of sterile needles by the methods of direct harvesting fungal propagules were directly transferred to culture medium agar-water (AA) (35 g agar to $1000 \mathrm{~mL}$ distillated water). After 48 hours, mycelial discs were transferred to a medium with potato-dextrose-agar culture (PDA) (15 g dextrose, $12 \mathrm{~g}$ agar, and $200 \mathrm{~g}$ of potato on 1000 $\mathrm{mL}$ distillated water). The plates (isolation and replication) remained incubated in a growth chamber at $25^{\circ} \mathrm{C}$, under a photoperiod of 12 hours of light per 48 
hours. During, the plates remained incubated for seven days under the same conditions.

From the main culture prepared one suspension of spores was obtained monosporic culture. This suspension of conidia in sterile distilled water was produced, being scratched by the method "stretch mark square" (the same method used in bacteriology). After 24 hours, it was selected unique and isolated colonies that were transferred (mycelial disks) to Petri dishes containing the PDA culture, there by producing monosporic colony. This cultivation remained incubated at $25{ }^{\circ} \mathrm{C}$ for 72 hours. The isolate was deposited in the collection and used for in vivo for inoculation biological tests.

After pathogen isolation on PDA culture medium and sporulation in growth chamber, semi-permanent slides were prepared for observation of specimen differences, both arising directly from the host as well as from artificial form. Fungal structures were removed tweezers and transferred to microscope slides containing fastener lactophenol fuchsin (1 mg of acid fuchsin, 2.6 $\mathrm{mL}$ of glacial acetic acid, $62.5 \mathrm{~mL}$ of lactic acid, 100 $\mathrm{mL}$ of glycerin and $100 \mathrm{~mL}$ of distilled water), and covered with a glass coverslip. The fungal structures morphometric (100 units by conidiophores, conidiogenous cells and conidia) was performed with an optical microscope, and the aid of the "ToupView ${ }^{\circledR}$ software. The digital photomicrographs were arrangement in groups by symptom and signals.

The range host and pathogenicity test were carried out on tomato fruit, as well as okra, bell pepper, eggplant, noni and zucchini (repeated 3 times); from which six discs of PDA culture medium, containing the pathogen, were cut for each test. The pathogenicity test was conducted in two different manners. The fruit were subjected to disinfestation for $3^{\prime}$ min with a water solution of sodium hypochlorite [1 \% 1 , and subsequently rinsed with sterilized distilled water. Then, they were distributed in boxes, containing two superposed sheets of blotter paper, soaked in sterile distilled water, together with a plastic ring (sterile) on which the fruit was placed (no direct contact with the moistened paper). Then, three discs $(10 \mathrm{~mm})$ were inoculated directly on the fruit for the first, and three discs were inoculated with a sterile needle on the punctured fruit for the second, and the other fruit without injury was inoculated of discs too. The boxes remained incubated for 12 days in growth chamber, until the observation by occurrence and symptom of the fungus sporulation. Twelve days after the inoculation, the development of the pathogen and its symptoms were analyzed (presence and absence symptom). With the aid of a ruler the lesion size $(\mathrm{cm})$ was also measured after 12 days of incubation. Later, the organism was isolated again in PDA medium (Koch's Postulate).

\section{Results and Discussion}

\section{Morphological and morphometric identification of the Corynespora isolate.}

The isolate artificially reproduced in artificial culture medium with 12-day incubation period. The pathogen structures observed on the semi-permanent slides, both on the ones made directly from the host and on the ones made artificially (derived from isolation and monosporic culture), didn't show morphometric and morphologic differences. It was noticed low abundance in spore production in PDA medium.

The lesions caused by $C$. cassiicola are basically found on fruit and leaves, especially in the post-harvest period, causing the rot of plant tissue (Figure 1A). Flocculent, spherical and confluent lesions of $26.3 \mathrm{x}$ $25.8 \mathrm{~mm}$ diameter, with depressions ranging from 9 to $20 \mathrm{~mm}$ diameter, were observed on the fruit 12 days after inoculation of the pathogen (Figure 1C). The presence of a grayish black halo in the center, and peripherally whitish to light gray, was observed as well (Figure 1B). The injury became whitish in an advanced stage of development (Figure 1C).

The plant pathogen grow mycelium was white and flocculent in PDA culture medium, where with each passing day it became of color dark gray, forming a tangle of olive black color on the tomato surface, when in an advanced development stage as Snow and Berggren, (1989), Ellis (1971) and Seaman et al. (1965) describe. These same cultural characteristics were observed too by Almeida (1994), with its isolate having slow growth in PDA medium, and forming a dark shade of gray-green color mycelium.

The Urutaí isolate, presented itself as stomatal esporodoquia, from which the esporodoquia emerged through the stomata ostiole of the tomato fruit, in the form abundance of mycelium (Figure 1C). The conidiophores were erect or curved (Figure 1G), branched, septate, with brown coloring, and measuring 285,0-(195,1)-122,0 x 11,6-(6,4)-4,3 $\mu \mathrm{m}$. The conidiogenous cell was enteroblastic, so the conidia formation occurred involving the internal layer of the cell wall, measuring 61,6-(39,8)-12,5 x 8,4-(6,3)-4,7 $\mu \mathrm{m}$ (Figure 1Ee1). The conidia measure 7-36 x 229 to 13,6 $\mu \mathrm{m}$; have variable form, clavate (Figure $1 \mathrm{G}$ ), cylindrical (Figure 1K), straight or slightly curved to the apex (Figure 1I), pseudo-septate (Figure 1J) or septate (Figure 1D); and variable coloration from hyaline (Figure 1M) to dark staining (Figure 1H) (Table 1).

The pathogen produces cultures with gray to brown coloration, and with no stroma (ELLIS, 1971). The conidiophores are erect, branched, with up to 20 septate, brown in color, and measuring 4-11 x 44-135 $\mu \mathrm{m}$ (SNOW; BERGGREN, 1989), and 4-1 x 110-850 $\mu \mathrm{m}$ (ELLIS, 1971). 
Table 1. Morphological and morphometric characters of the isolate Corynespora sp. from Urutaí (2012) and the characters from descriptions by Ellis (1971) and Snow e Berggren (1989).

\begin{tabular}{|c|c|c|c|}
\hline Fungi charters & Isolate Urutaí, GO (2012) & Ellis (1971) & Snow e Berggren (1989) \\
\hline \multicolumn{4}{|l|}{ Media } \\
\hline Coloration & Gray to black & Gray to brown & NR \\
\hline Presence of stroma & Absent & Absent & NR \\
\hline $\begin{array}{l}\text { Abundance of conidia } \\
\text { production }\end{array}$ & Little & NR & NR \\
\hline \multicolumn{4}{|l|}{ Conidiophore: } \\
\hline Form and septation & Upright or curved, branched, septate & $\begin{array}{l}\text { Upright, septate, and of } \\
\text { intermittent ramification }\end{array}$ & NR \\
\hline Coloration & brown & brown & NR \\
\hline Dimensions $(\mu \mathrm{m})$ & $285,0-(195,1)-122$ x 11,6-(6,4)-4,3 & $850-110 \times 4-1$ & $135-44 \times 4-11$ \\
\hline Proliferation of conidiophore & NR & 9 & NR \\
\hline \multicolumn{4}{|l|}{ Conidiogenous cell: } \\
\hline Conidiogenesis & Enteroblastic & Enteroblastic & NR \\
\hline Dimensions $(\mu \mathrm{m})$ & $61,6-(39,8)-12,5 \times 8,4-(6,3)-4,7$ & NR & NR \\
\hline \multicolumn{4}{|l|}{ Conidia: } \\
\hline Form & $\begin{array}{c}\text { Clavate and variable, cylindrical, } \\
\text { straight or curved }\end{array}$ & $\begin{array}{l}\text { Clavate and variable, cylindrical, } \\
\text { straight or curved }\end{array}$ & $\begin{array}{l}\text { Variable from straight to } \\
\text { curved, subcylindrical, } \\
\text { slightly conical }\end{array}$ \\
\hline Coloration & Hyaline to dark brown & Sub-hyaline to brown & Hyaline to brown \\
\hline Surface & Smooth & Smooth & Smooth \\
\hline Conidia production & Alone or in chain & Alone or in chain (2-6) & NR \\
\hline Dimensions $(\mu \mathrm{m})$ & $229-13,6 \times 7-36$ & $220-40 \times 9-22$ & $520-39 \times 7-22$ \\
\hline Base lenght $(\mu \mathrm{m})$ & NR & $4-8$ & $\mathrm{Nr}$ \\
\hline Number of pseudosepta & 18 & $4-20$ & $3-20$ \\
\hline Pseudoseptation & Present & Present & Present \\
\hline Septation & Present & Present & Present \\
\hline
\end{tabular}

*NR $=$ not reported.

The hyaline conidia have brown coloring, dilated at the base, straight or slightly curved and tapered to the apex, subcylindrical with 3-20 septa, measuring 7-22 x 39-520 $\mu \mathrm{m}$ (SNOW; BERGGREN, 1989) and 9-22 x 40-220 $\mu \mathrm{m}$ (ELLIS, 1971) (Table 1).

The following are the results of the comparative analysis of morphological and morphometric characters of the Corynespora sp. isolate from Urutaí, GO (2012) and Ellis (1971). Both cultures presented coloration ranging from gray to black, and the absence of stroma. The compared conidiophore had the same form and septation, being erect or curved, septate and branched with brown coloration and similar morphometry.

The conidiogenous cell was characterized as enteroblastic in both descriptions. Conidia were characterized as being variable, clavate or obclavate, cylindrical, straight or curved with hyaline to dark staining, and with smooth surface (Figure 1 D-M). The conidia were produced in chains or alone, with the presence of true septa and pseudosepta, with dimensions that met only the description of Snow and Berggren (1989). It was observed that the color difference of the conidia was directly linked to the state of maturation of the cell. According to morphological and morphometric descriptions, and in line with Ellis (1971) and Snow and Berggren (1989) listed in Table 1, the isolate was identified and characterized as being C. cassiicola.

Hosts and pathogenicity of Corynespora sp. on some vegetables

The isolate tested on treatments with injury was pathogenic on okra, bell pepper, and tomato; and avirulent in three experiments repeated on eggplant, noni, and zucchini (Table 2). In contrast, in treatments 
without wound the isolate was pathogenic for the original host (tomato species-specific reaction), and no pathogenic for the other hosts tested (Table 2). As in this work, Olive et al (1945), the fungus develops sand sporulates in different media, however the PDA It was the best, because this It chose for greater sporulation.

According to Cutrim and Silva (2003), two isolates of C. cassiicola originated from tomato, presented high variability in pathogenicity when inoculated into several agronomic species such as pumpkin (Cucurbita pepo), gherkin (Cucumis anguria), bell pepper (Capsicum annuum), okra (Abelmoschus esculentus), soybean (Glycine max), tomato (Solanum lycopersicum), hibiscus (Hibiscus sabdariffa), spiderwort weed (Commelina benghalensis) and Vernonia weed (Vernonia cinerea). This experiment the pathogenicity presented low variation (Tab. 2), possibly by inoculating in a larger number of host the variation of pathogenicity increase.

The identification by $C$. cassiicola as the causal agent due to the variability of symptoms, inconsistencies in the sporulation of the pathogen, morphology, and competitive growth ability. At first the pathogen establishes itself on the host's leaves, but later it spreads to other vegetative parts such as stems and fruits, as in papaya and tomato. In most hosts, the lesions are small and discrete with about $10 \mathrm{~mm}$ diameter. Larger peripheral lesions occur as well (Figure 1ABC).

Isolates from the Pacific Basin (American Samoa, Guam, Hawaii, Palau, Saipan, Yap, and Pohnpei) also identified pathogenicity in tomato. The crops that sufferthe largest production reduction include cowpea (Vigna unguiculata), cucumber (Cucumis sativus), papaya (Carica papaia), bell pepper (Capsicum spp.), Pará rubber tree (Hevea brasiliensis), soybean (Glycine max) and tomato (Solanum lycopersicum), revealing that for the tomato pathossystem - $C$ cassiicola, this condition presents itself as a possible emerging disease (SCHLUB, 2008).

According to Oliveira et al. (2007), the pathogen $C$. cassiicola originated from soybean, squash, tomato, papaya, lantana, acerola cherry (PAPA, 2005), lettuce, long pepper, false boldo, spiderwort, and vernonia weed, was pathogenic to the crops of papaya, cucumber, giant pumpkin, soybean, lettuce, spiderwort, vernonia, and tomato (the host evaluated in this research).

The isolates originated from different hosts may differ as to the pathogenicity and may have different ranges of hosts, therefore the isolate $C$. cassiicola originated from a host will not necessarily be able to infect other host species due to the tomato cultivar interactions $-C$. cassiicola environment.
Late 12 days after inoculation was observed with abundant surface mycelium of the pathogen, covering more than $40 \%$ of the surface of the inoculated fruits of okra, suit pepper and tomato, whereas in rubber leaves was identified the formation of germinative tubes by Liu et al. (2014) after 4 hours, and the abundant production of surface mycelia was observed after 24 hours (2 days). In this way, we highlight that the number of hours has been variety according host plant, pathogen and environment interaction between (AMORIN et al., 2011) - concept of plant disease.

Table 2. Pathogenicity of Corynespora sp. isolate in different hosts, and in treatments with and without injury after 12 days.

\begin{tabular}{lcc}
\hline Hosts & With Wound & Without Wound \\
\hline Okra & + & - \\
Bell pepper & + & - \\
Tomato & + & + \\
Eggplant & - & - \\
Noni & - & - \\
Zucchini & - & - \\
\hline
\end{tabular}

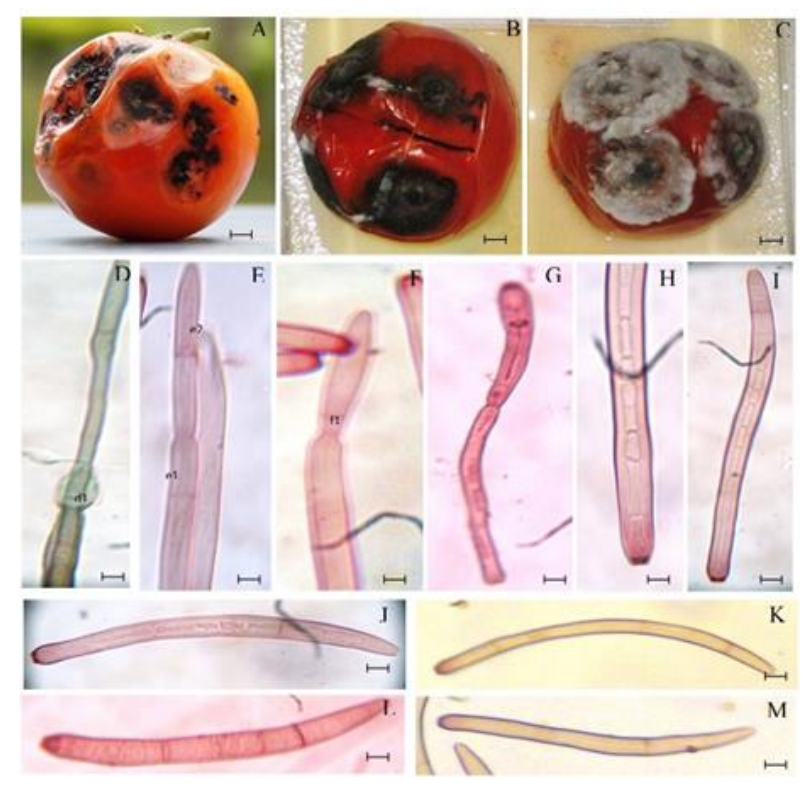

Figure 1. Tomato fruit rot (Lycopersicon esculentum) caused by Corynespora cassiicola. A. Natural symptom of rotten fruit (bar $=8 \mathrm{~mm})$, B. Artificial symptom of rotten fruit inoculated without injury (bar $=3,1 \mathrm{~mm}$ ), C. Artificial intermediate symptom of rotten fruit inoculated in treatment with injury, with abundant secession and production of greyish mycelium (bar $=3,4 \mathrm{~mm}$ ), D. Secession fragment and conidiophore stretching $(\mathrm{d} 1)(\mathrm{bar}=8 \mu \mathrm{m})$, E. Conidiogenic cell (e1) and bicelular conidia (e2) $(\mathrm{bar}=5,3 \mu \mathrm{m}), \mathrm{F}$. Constriction during conidiogenisis (f1) (bar = 7,3 $\mu \mathrm{m})$, G. Conidiophore, curved conidia and clavate (bar $=8 \mu \mathrm{m}), \mathrm{H}$. Truncate basis of conidia pseudoseptade and basis showing wall scars (bar $=7,8 \mu \mathrm{m}$ ), I. Conidia pseudoseptade and rounded basis showing wall scars (bar $=8,2 \mu \mathrm{m}$ ), J. Mature, pale and pseudoseptade conidia (bar $=8,2 \mu \mathrm{m}$ ), K. Curved and slim conidia with true septation (bar $=8,1 \mu \mathrm{m}$ ), L. Curved and wide conidia with true septation (bar $=8,1 \mu \mathrm{m}$ ), M. Lightly curved conidia with true septation (bar $=8,2 \mu \mathrm{m})$. 
The presence of wounds (Tab. 2) in the tested hosts allowed an increase in the infectivity of the C. cassiicola isolate from tomato, proving the non - specificity of the isolodate tested by this favorability to the occurrence of the disease. In post-harvest conditions, these injuries would cause severe damage and reduce post-harvest life.

\section{Conclusions}

It was verified that the pathogen artificially reproduced the natural symptoms proving it's pathogenicity both with and without wound.

The pathogen was more aggressive in wound treatments in okra, bell pepper and tomato.

Through morphological and morphometric characteristics, this isolate was identified and characterized as being Corynespora cassiicola.

\section{Bibliographic References}

ALMEIDA, A. M. R., Diferenciação de isolados de Corynespora cassiicola. Fitopatologia Brasileira, BrasíliaDF, v. 29, (suplemento), p. 316, 1994.

ALMEIDA, A. M.; MACHADO, C. C.; FERREIRA, L. P.; LEHMAN, P. S.; ANTONIO, H. Ocorrência de $\boldsymbol{C}$. cassiicola (Berk. \& Curt.) Wei no Estado de São Paulo. Fitopatologia Brasileira, Brasília-DF. v. 1, n. 1, p. 111-112, 1976.

AMORIM, L.; REZENDE, J. A. M.; BERGAMIN FILHO, A. Manual de Fitopatologia - princípio e conceitos, 4. ed., v. I, São Paulo-SP: Editora Agronômica Ceres, 2011, 704 p.

CUTRIM, F. A.; SILVA, G.S. Patogenicidade de $\boldsymbol{C}$. cassiicola a diferentes espécies de plantas. Fitopatologia Brasileira, Brasília-DF, v. 28, n. 2, p. 193-194, 2003.

ELLIS, M. B. Dematiaceous hyphomicetes. Kew Surrey, UK: Common Wealth Mycological Institute, CAB, 1971. 608 p.

FARR, D. F.; ROSSMAN, A. Y. Fungal Databases. Systematic Mycology and Microbiology Laboratory, ARS: USDA. 2018. Disponível em: <http://nt.arsgrin.gov/fungaldatabases/>, Acesso em: 05 jan. 2018.

HENZ, G. P.; MORETTI, C. L. Tomate: Manejo pós-colheita. Revista Cultivar Hortaliças e Frutas, Brasília-DF, v. 30, n. 2, p. 24-26, 2005.

HUANG, H. K.; LIU, C. E.; LIOU, J. H.; HSIUE, H. C.; HSIAO, C. H.; HSUEH, P. R. Subcutaneous infection caused by $C$. cassiicola, a plant pathogen. Journal of Infection, British, UK, v. 60, n. 2, p. 188-190, 2010.

INDEX FUNGORUM, Banco de dados para consulta de táxons fúngicos. Disponível em: <http://www.speciesfungorum.org/Names/SynSpecies.asp?Re cordID=296024>, Acesso em: 08 maio 2015.
LEROY, M.; LOURD, M. Doença foliar do tomateiro causada por C. cassiicola em Manaus. Fitopatologia Brasileira. Brasília-DF, v. 4, n. 1, p. 32-36. 1989.

LIU, X. M.; QI, Y. U.; ZHANG, X.; XIE, Y. X.; ZHANG, H.; WEI, Y. X.; CAO, S. W.; PU, J.J. Infection process of Corynespora cassiicola tagged with GFP on Hevea brasiliensis. Australasian Plant Pathology, Queensland, Australia, v. 43, n. 5, p. 523-525, 2014.

LOPES, C. A.; SANTOS, J. R. M. Doenças do tomateiro. Brasília-DF: Embrapa-SPI, 1994. 67 p.

LOPES, C. A.; AVILA, A. C. Doenças do tomateiro. Brasília-DF: Embrapa Hortaliças, 2005, 151 p.

NAIKA, S.; JEUDE, J. L.; GOFFAU, M.; HILMI, M.; VAN DAM, B. A Cultura do Tomate: produção, processamento e comercialização. Wageningen, Holanda: Fundação Agromisa e CTA, 2006. p. 6-11.

NASCIMENTO, L. N.; SILVA, B. A., SILVA, A. R. Revista Hortifruti Brasil: Tomate. Ed. 133. São Paulo-SP: CEPEAUSP/ESALQ, 2014. p. 24-25.

OLIVE, L. S.; BAIN, D. C.; LEFEBVRE, C. L. A leaf spot of cowpea and soybean caused by undescribed species of Helminthosporium. Phytopathology, St. Paul, USA. v. 35, p. 822-831, 1945.

OLIVEIRA, R. R.; VIDA, J. B.; TESSMANN, D. J.; AGUiAR, B. M.; CAIXETA, M. P.; BARBOZA, A. A. L. Patogenicidade de isolados de $C$. cassiicola a diferentes espécies de plantas. Summa Phytopathologica, Botucatu-SP. v. 33. n. 3. p. 297-299. 2007.

PAPA, M. F. S. Doenças da acerola (Malpighia emarginata). In: KIMATI, H.; AMORIM, L.; REZENDE, J. A. M.; BERGAMIN FILHO, A.; CAMARGO, L. E. A. Manual de fitopatologia: doenças das plantas cultivadas. 4 ed. v. 2. São Paulo-SP: Agronômica Ceres, 2005. p. 15-18.

PERNEZNY, K.; SIMON, G. W. Target spot of several vegetable crops. Plant Pathology, London, UK, v. 39, n. 1, p. 39-43. 1999.

SCHLUB, R. L. Characterization of the species $C$. cassiicola and its impact on quarantine regulations. Mangilao: National Institute of Food and Agriculture. University of Guam, UOG Station, 2008. p. 1-2.

SEAMAN, W. L.; SHOEMAKER, R. A.; PETERSON, E. A. Pathogenicity of $C$. cassiicola on soybean. Canadian Journal Botany, Montreal, Canadá, v. 43, n. 11, p. 1461-1469, 1965.

SILVA, J. B. C.; GIORDANO, L. B. Tomate para processamento industrial. Brasília-DF: Embrapa Hortaliças, 2000. $335 \mathrm{p}$.

SILVA, W. P. K.; MULTANI, D. S.; DEVERALL, B. J.; LYON, B. R. RFLP and RAPD Analyses in the identification and differentiation of isolates of the leaf spot fungus $C$. cassiicola. Australian Journal of Botany, Melbourne, Austrália, v. 43, n. 3, p. 609-618, 1995.

SNOW, J. P.; BERGGREN JUNIOR, G. T. Target spot in: Compendium of soybean diseases. 3. ed. St. Paul, Minnesota: American Phytopathological Society, 1989. p. 27-28. 